\title{
GLOBALIZATION PHENOMENON AND ITS EFFECTS ${ }^{1}$
}

\author{
Kafkas University \\ Economics and Administrative \\ Sciences Faculty \\ KAUJEASF \\ Article Submission Date: 31.03.2021 \\ Accepted Date: 22.09.2021 \\ Vol. 12, Issue 24, 2021 \\ ISSN: $1309-4289$ \\ E - ISSN: 2149-9136
}

\section{Selin AYAZ}

Asst. Prof.

Kafkas University

Faculty of Economics and

Administrative Sciences,

Kars, Turkey

selinayaz81@gmail.com

ORCID ID: 0000-0002-6683-9461
ABSTRACTI Globalization is

a word that probably heard and used by everyone in all regions of the world. The developments in communication, telecommunication, transportation and logistics opportunities brought by the information and the age of technology geographical boundaries can easily be crossed. The world has almost turned into a "global village" and this transformation caused positive and negative effects in economic, social, cultural, political dimensions for nation-states, institutions, societies and individuals. This impact and transformation built a "New World Order" as this new order created an environment of uncertainty. The future anxiety caused by this uncertainty triggers social discomfort and even chaos. Globalization is designated as both the cause and the outcome of this new world order. Globalization phenomenon, used for the first time to define the global root-to-branch transformation in 1833, was the center of discussion ever since its introduction to academic circles. This study analyzes the globalization phenomenon with its essential features, and the concepts and systems it transformed will be evaluated with a holistic approach.

Keywords: Globalization, glocalization, corporatocracy.

Jel codes: A1, F01, F02

Scope: Economics

Type: Review

DOI: 10.36543/kauiibfd.2021.048

Cite this Paper: Ayaz, S. (2021). Globalization phenomenon and its effects. KAUJEASF, 12(24), 1199-1217.

\footnotetext{
${ }^{1}$ Compliance with the ethical rules of the relevant study has been declared.
} 


\section{KÜRESELLEŞME OLGUSU VE KÜRESELLEŞMENIN ETKILLERI}

Makale Gönderim Tarihi: 31.03.2021 Y
Selin AYAZ
Dr. Öğr. Üyesi
Kafkas Üniversitesi
İktisadi ve İdari Bilimler Fakültesi,
Kars, Türkiye
selinayaz81@gmail.com
ORCID ID: 0000-0002-6683-9461

ORCID ID: 0000-0002-6683-9461
Yayına Kabul Tarihi: 22.09.2021

\section{ÖZI}

Son y1llarda her kesimden herkesin sıkça duyduğu ve kullandığı bir kelime küreselleşme. Yaşadığımız bilgi ve teknoloji çağının beraberinde getirdiği haberleşme, iletişim, ulaşım, lojistik imkânlarındaki gelişmelerle beraber coğrafi sınırlar kolaylıkla aş1labilir olmuş, dünya neredeyse "küresel bir köy"e dönüşmüş ve bu dönüşüm; ulus-devletler, kurumlar, toplumlar ve bireyler üzerinde ekonomik, sosyal, kültürel, politik vb. birçok yönden olumlu-olumsuz etkiler ve değişimler yaratmıştır. Bu etki ve değişimler sonucu "Yeni Dünya Düzeni” oluşmakta ve bu yeni düzen beraberinde bir belirsizlik ortamı yaratmaktadır. Belirsizliğin getirdiği gelecek kaygısı toplumsal huzursuzlukları ve bazen kaosu tetiklemektedir. Küreselleşme bu yeni dünya düzeninin hem sebebi hem de sonucu olarak gösterilmektedir. Küreselleşmenin kelime olarak ilk kez kullanıldığı; yani dünyanın her alanda değişiminin adının konulduğu, 1833 yılından bugüne, tüm akademik çevrelerde üzerinde en çok tartışılan olgulardan biri olmuştur. $\mathrm{Bu}$ çalışmada; hem küreselleşme olgusu ana hatlarıyla ele alınacak hem de dönüştürdüğü kavram ve sistemler bütüncül bir bakış açısıyla değerlendirilecektir.

\section{Anahtar Kelimeler: Küreselleşme,} küyerelleşme, şirketokrasi.

JEL Kodu: A1, F01, F02

Alan: İktisat

Türü: Derleme 


\section{INTRODUCTION}

There is a term in our lives more frequently, especially with the widespread use of computer technologies, and constantly mentioned in media, scientific environments and our daily lives for the last 40 years, that is, since the 1980s. What is globalization anyway? Is it a good or a bad thing? What are its advantages and disadvantages? Whom it benefits and harms? Is it a beautiful dream or a nightmare for the world? Is it an opportunity or a threat? Is it a trend used as the word to catch up with the agenda in all platforms, especially in social sciences? Is globalization, which makes all countries of the world more interdependent regardless of their development level, the provider of foreign savings and investments necessary for underdeveloped and developing countries to break the vicious cycle of poverty? Moreover, is it a process that exposes such countries to the impositions of developed hegemonic countries, which further widen the gap in the world income distribution?

All concepts and systems have undergone an intense transformation, which changed observations and perceptions within the current technology and information world. The globalization phenomenon causing economic, social, political, cultural and ecological transformations is also supported by the implications of these changes. Furthermore, the world changes as it globalizes and becomes global as it changes.

Globalization, which has affected almost all nations of the world in every aspect, has primarily increased international economic relations and their interdependence. This also affects the political, social, cultural orientation, perception and foreign policies of these states as these states cannot act apart from others while this change implies all decision-making processes. Although some events in the world occasionally reduce this interdependency, it is evident that globalization will maintain its upward trend and stay relevant word for a long time.

\section{AN OVERALL REVIEW OF GLOBALIZATION}

The globalization concept was introduced to the literature with the article of British economist W. Foster in 1833 on the distribution and usage of resources globally and was cited in The Economist magazine on April 4, 1959. This concept became popular in 1968 when Garett Hardin included this word in his article. (Karabıçak, 2002, p. 116).

Globalization is a process that has transformed great concepts, and its effects reflect in all societies and institutions. The conceptual framework of globalization is studied within a broad scope and it is not easy to make a precise definition. This section is designed to proceed in the following order. First, the historical development of globalization will be briefed through definitions of 
globalization. Second, international organizations integrated with globalization will be analyzed, and globalization approaches will be summarized.

\subsection{Making Sense of Globalization}

Globalization has several definitions, such as a system in which the internationalization process is actualized, non-regional production and consumption are planned on a world scale, free competition and market order are controlled by supranational organizations, and the rules act with a supranational understanding (Kutlu, 1998, p. 175). It is also defined as a process that enables global experience sharing by shortening the time and distance with the facilities provided by technology (Gray, 2006, p. 94). It is the downsizing of the world and the widespread vision of the world as a single place (Aslanoğlu, 1998, p. 124125). McLuhan argued that the world has turned into a "global village" that keeps getting smaller with technological improvements and the rapid flow of information (Mcluhan, 2014). Giddens defined globalization as the concentration of social relations globally as the developments in one country affect other countries or states, and societies are being affected by the events outside the national borders (Giddens, 1990).

The anti-globalization promoters define globalization as the process of transnational structuring of capitalism by spreading to the world and forming the ideological and systematic basis for hegemonic countries' impositions. It is also defined as the internationalization of production, consumption, investment and finance by reducing or even removing barriers to the flow of goods and services in a broader context. The connection between modernity and capitalism that brought along globalization is mutual as their existence conditions are dependent on each other but cannot be reduced to each other (Keyman, 2000, p. 34).

Although globalization is a phenomenon that needs to be addressed in social, political, cultural, ecological dimensions, a central focus on the economic aspect is almost necessary. The dynamics present in the production, circulation, and consumption of goods at every stage of capitalism substantially impact our increasing interdependence between societies. However, this does not mean that the economic analysis of transnational capitalism is the most crucial component in understanding globalization (Tomlinson, 2017, p.33).

\subsection{History of Globalization}

The history of globalization includes intellectual liberal thinkers such as Murray Rothbard and David Friedman. These intellectuals have placed the market freedom principle at the center of their work since the 1970s. Thus the liberal ideology of "laissez-faire" becomes a norm. This liberal discourse derives its source from the Austrian School of Economics scholars represented by Ludwig von Mises and Friedrich von Hayek (Tutal, 2006: pp. 22-23). 
The globalization activity level in the world is divided into four categories: First Globalization Period 1870-1914, Return to Nationalism Period 1914-1945, Second Globalization Period 1945-1980, New Globalization Period from 1980 until the present day (Dikkaya \& Üzümcü, 2017, p. 124). The actual rise of globalization occurred with the technical developments in informationprocessing, communication, transportation, logistics etc., experienced in the world after the 1980s as the financial markets and capital movements have been liberalized, internationalization policies and the popularity of the neo-liberal trend increased all over the world.

Globalization has also gained its own corporate identity through international organizations. The search for a new world order after World War II led by the USA was influential in forming this identity. An attempt was made to create triple complimentary tenets, namely the IMF (International Monetary Fund), WB (World Bank) and firstly the GATT (General Agreement on Tariffs and Trade) and then the WTO (World Trade Organization) in this regard. Although the international organizations within the UN (United Nations) were also implemented, the global efficiency of these organizations has not been as great as the first three (Dikkaya \& Özyakışır, 2008, pp. 97-98).

Arguably, almost no state today can exclude itself from specific regulations from the foreign policy perspective. The states, especially economically, cannot stay outside of organizations such as the WTO and the IMF as they face the obligation to accept the conditions stipulated by these organizations. It can be asserted that the economic integration brought about by globalization has narrowed the state sovereignty over the economy in this sense (Kazgan, 2000, p. 221). Moreover, the companies that have reached a global character beyond political powers, especially financial capital, are fundamental actors in realizing an ideological program such as global capital accumulation (Yeldan, 2003, p. 449). This power acquired by transnational corporations with international organizations' support leads to a global control mechanism and political domination by these structures.

The Bretton Woods system, the IMF and the World Bank, and the idea that the US is the center of the world was strengthened as this situation was defined as "Pax Americana "by Robert Cox (1986, p. 223). Globalization is also called "Americanization" as it is rooted in the active and enthusiastic role of the US on the liberalization and globalization of the world politics, from its hegemonic position in the world, and the transformation of the world into an American-like consumer society with its dominant and expansionist culture.

Globalization approaches are divided into three as Extreme Globalizers, Skeptics and Transformationist scholars with a more neutral approach to this 
process (Bozkurt, 2000, p. 18). The pro-globalization supporters argue that the world cannot escape from it, every country will be included in this absolute process, and world welfare can only be achieved through this process. The skeptics defend that globalization is the cause of global crises, and it is the systemized form of imperialism. On the other hand, transformation supporters do not reject globalization but do not promote it as the perfect savior.

\section{THE EFFECTS OF GLOBALIZATION}

Globalization has affected and transformed almost all concepts and systems globally, especially with technology and informatics developments. What awaits humanity in the future due to the speed, uncertainty and risk factors brought about by globalization? It is ideal that the effects of globalization, especially in the last half-century, should be observed and interpreted from an objective perspective and countries should evaluate the pros and cons of globalization in line with these inferences and shape their plans with this strategy. In the new order that is formed in the changing world, it is seen that countries can come to the fore with their ability to carefully follow the ongoing globalization efforts of the countries in the race to gain a remarkable position, add the positive aspects of globalization to their structure and turn them into opportunities, and produce defense and dissolution mechanisms against the negative aspects. Therefore, the dimensions of globalization and its effects on concepts are evaluated.

\subsection{Globalization and Economy}

Although globalization is a process that affects all concepts and systems globally, its engine is the economy. The new economic order, understanding, and systems formed within globalization and economic relations between countries intensify and produce brand new dimensions. Advanced communication, transportation, and logistics networks facilitated the through adaptation of the "let them do, let them pass" philosophy, international trade has intensified, crossborder movement of production factors such as capital and labor has become easier and faster, and production models have evolved from local centers to a much more mass-production model. Similar products were taken as a basis in producing goods and services with similar desire and demands of the societies as the production patterns became standardized. Consumer goods have diversified, and product quality has increased with increasing competition in the markets. However, this consumption-oriented economy has also terminated most smallscale and local businesses that cannot cope with rising costs and compete with large global companies.

Nation-states have implemented domestic policies to flourish environments that encourage foreign direct investments. This process brought 
positive implications, especially in less developed and developing countries, to achieve certain standards in law, democracy, work safety and social security, quality and infrastructure for production and living standards. Moreover, it has become even more critical for countries to ensure stability in fundamental macroeconomic indicators such as inflation, employment and interest to have a strong position in the globalizing world economy. Notably, the increase in digital international financial capital flows based on speculation, establishing strong internet, banking and insurance systems on legal grounds is perceived as a code to catch up with the modern age.

Despite all these positive developments, claiming that the borders have completely lost their significance is not acceptable although they became more permeable owing to the influences of the capital and the globalization. Nor is it possible to say that globalization hasled to the formation of a universal community in this aspect (Nye \& Welch, 2010, pp. 342-343). Also economic relations became intertwined, and everything functioned with "speed", national economies became much more dependent on international developments and decisions as the number of economic crises increased with more fundamental impact. Furthermore, it is understood that the global economy can bring the less developed and developing countries into a modern colony of developed countries considering the dominance of developed countries in the economic sphere. The indirect investments flown into another country with a click can increase the amount of capital in that country, but in the slightest risk environment, it is just as easy for this capital to escape suddenly as this cause uncertainty and even lead to an atmosphere of chaos and crisis. States prefer foreign direct investments in this regard for more permanent and productive capital.

Foreign direct investments provide employment opportunities and capital increase in target countries, and they transfer the production technologies of developed countries to local employees with its learning model. The risky aspect of such investments is that multinational companies can influence critical points in the target countries thanks to their global power and advantages, and they can assume an active role in these states' economies. This means that multinational global companies gain leverage in shaping target countries' economies and direct them within their goals. There may also occur risks of local resource exploitation, cheap labor and capital by the corporatocracy.

What is interesting here is that the capital flows have become interested not only in a few "favorite" countries that adopt the "correct" macroeconomic policies but also innumerous economies that differ extremely in terms of their structures and economic policies with the same resolution and speed. In that sense, we can see that the international capital movements of the 1990s were not 
limited to one or two geographical regions, but they have formed a new stage of world capitalism on a global scale. Containing the dimensions of globalization manifested by international finance-capital in investment decisions on one hand and the articulation of world financial markets on the other, this process draws the national markets into an area of speculative interests one by one, being backed by the dizzying developments in the communication technology (Yeldan, 2002, pp. 29-30).

It is also clear that globalization has increased opportunities for tax avoidance and even facilitated tax evasion. Companies can make production in a country or a state with low tax rates and sell their goods anywhere in the world. A company can establish its intellectual property rights in a country with low tax rates and claim that most of its profits are attributable to intellectual property rights. In this case, even the country where the goods are produced will not earn much tax revenue. The excessive freedom to locate production and decide on where profits will be actualized, tax competition and the race to the bottom have gotten worse (Stiglitz, 2018, pp. 124-125).

\subsection{Globalization and the Nation-State}

The nation-state is old. Borders do not function anymore. Distance is now a hollow concept. The world is not divided into parts. Our identities are no longer tied to our birthplace. Local politics has been replaced by newer and more fluid forms of international representation. Power is shifting from the hands of local regulators to transnational regulatory networks. Political power is shifting to the new movement of activists gathering around international civil organizations. The decisions that shape our economic lives are taken by large multinational companies and unrecognized international bureaucrats (Rodrik, 2011, p.183).

It is observed that globalization, whose existence becomes more practical each day through the multifaceted developments globally, is in conflict with the nation-state in its political structure. Since globalization is a process targeting the removal of geographical borders and completely integrating countries, it does not adapt to the nation-state. The concept of border is always emphasized within the nation-state definition as this contradicts the goals of globalization. Nation-state boundaries are an outcome of institutional management with an administrative monopoly on a particular area, which binds internal and external violence to control sanctions with laws (Weber, 1985, p. 56). Globalization limits the modern nation-state in "cultural leveling" (homogenization) and reduces sovereignty (Hirst \& Thompson, 1998, p. 214).

The impediments on sovereignty undermine the nation-state's ability to compensate the losses of victims and reduce social tensions. Increasing inequalities with the process of transferring certain areas of national sovereignty 
exacerbates social conflicts and threaten democratic institutions (Przeworski, 1994, pp. 56-76).

The logic behind the ideology of globalization is the profitability of capital as a primary condition for efficient resource allocation and thus increasing economic welfare. This condition is only possible through a "free market economy" that is completely deregulated. This design considers all kinds of investments in education, health and social infrastructure through supply and demand signals of the market economy and financial cost-benefit analysis as in all other investment expenditures. Thus, all direct non-profit initiatives of the national state in these areas are designated as "inefficient", and the social infrastructure is increasingly privatized at market prices. Therefore, there are two strategic goals for the capital, which wishes to increase its profitability by transforming the world economies into a single market: limiting the supervisory power of national states and removing the gains of labor organizations (Yeldan, 2016, pp. 24-25).

Therefore, it is too early to say that the nation-states will retreat from the world stage and lose their functionality while facing the reality that globalization disrupts the traditional role of the nation-state, which is a challenge for nationstates. The globalization process facilitated the adaptation of traditional regulations in every field to international norms, and the sharp distinctions between domestic and foreign policies are reduced. Briefly, a postmodern world that transforms from the nation-state system to a global system is being established.

\subsection{Globalization and Localization}

Localization, which is closely linked to globalization, also manifests itself with adverse effects on the independent decision-making and implementation process in nation-states. Anti-localization supporters argue that local governments will eventually have the power of self-government as their powers increase, and this shall transform nation-states into provinces of regional or continental, economic and political empires.

However, pro-localization scholars assert that increasing the local governmental powers shall improve human rights and democracy. It is emphasized that localization is essential in strengthening democracy and social structure. Thus, the national unity and existence of nation-states are eroded by localization. Localization brings ethnic structure and identities to the forefront (Bildirici, 2010, pp. 39-45). This promotes cultural aspects, nationalist feelings and individual identities, crystallizes the social classes, and harms the integrative structure of nation-states. 
Moreover, this does not occur through a multiculturalism accepted with a social consensus but through developments that increase divergences, contradictions, and social tensions. Besides this tense environment, ideological separations emerging due to anti-globalization, terror and security problems arise for nation-states.

\subsection{Globalization and Glocalization}

If globalization is considered processes simultaneously occurring in the economy, politics, culture, technology and similar fields with complex relationships, it is arguable that it also bears contradictions, resistance and contradictory forces. Moreover, a dialectical globalization vision that includes opposite principles and trends (such as local and global, universality and particularity) is becoming prevalent, especially in approaches that emphasize cultural issues (Tomlinson, 2017, p. 33).

Recently, the concept of glocalization is used frequently beside the concepts of globalization and localization. The global and local concepts are generally used in opposition to each other, and one has been adopted as a reaction to the other through dominant social trends. Globalization is a new concept that can reduce the conflict between these two contrasting concepts.

Robertson (1998, p. 174), who was one of the first to introduce this concept, argues that "Global", which is the macro aspect of contemporary life, and "local", a micro aspect, are intertwined concepts as a local phenomenon can become global and a global phenomenon can be localized. The most typical example is that a local newspaper (Aberdeen* Daily Journal) for the "Titanic Ship Disaster", one of the most significant global accidents of the century, occurred in 1912 (Aberdeen; is a city with the most important port and trade center located in Northeast Scotland) in the headline allegedly made reported that "The people of Aberdeen disappeared at sea" (Aberdeen man lost at sea) (Robertson, 1998, p. 174). A local newspaper in Scotland, Aberdeen Daily Journal, published this headline to establish a local connection to this international accident to grasp more attention by its local readers (Hobbs, 2005).

Although it was later understood that this headline was not in the newspaper, in the daily news bulletin hung on the window of a shop that sells the newspaper, it was accepted as the most critical example of how regional newspapers can seek a local perspective even in the most dramatic events in the world (Mackay, 2004). These types of headlines are still presented and discussed as examples of the localization of globalization.

\subsection{Globalization and Culture}

One of the most extensive impact areas of globalization is socio-cultural transformation. The primary consumption patterns such as dressing and eating 
habits and lifestyles, preferred music, movies and TV series, etc. briefly, feelings, thoughts and perceptions in all areas of life tastes, preferences and tastes, needs, desires and demands are becoming more and more homogenized day by day. These trends, observable in societies of all races and countries, are criticized positively/negatively by specific camps.

The primary source of globalization is developing communication opportunities. As the world's societies interact with each other, they get closer, and the cultural symbols are better familiarized and even adapted. This culture transfer process creates a more peaceful atmosphere in the world, enables individuals, minorities and differences to be more visible, defend their rights and make their voices heard, and at the same time triggers societies' search for a more democratic, just and liberal system.

Despite all these positive developments, the cultural homogenization in the world society is also a highly criticized aspect. It is thought that it will corrupt and destroy local cultures and create cultural imperialism by global powers imposing their culture on others. Moreover, certain groups that oppose this cultural homogenization led by globalization will face sharper divisions among themselves as ethnic, national, religious, sexist, local, regional movements will be triggered.

Modern societies in the process of globalization create an individualized, self-oriented human model raising people to the macro scale as this causes isolation and alienation in social life. Moreover, it is a fact that the central theme of global culture is an excessive consumption-oriented hedonist lifestyle.

Briefly put, technological development brings the world societies closer to each other. As this convergence creates positive factors, there are also adverse outcomes such as political and economic polarization. This polarization turns into the disintegration of ghettos, class and sub-identities in the immigrated big cities.

\subsection{Globalization and Education}

The new economic understanding which developed along with the globalization process has also brought out a new human resource model. A human resource that is open to learning and has access to culture and information sources is expected to have the skills to actively take part in integration with the world. In this regard, educational institutions are expected to bring up qualified human resources that can compete in the global economy and create added value in social and cultural policies (Tatlidil \& Esgin Günder, 2013, pp. 263-264).

The leading resource that globalization feeds on is undoubtedly the developing communication facilities, as the access to these opportunities requires infrastructure, it creates a particular cost for each country. Therefore, adapting to the information age and keeping up with it has become the primary goal of 
countries. The idea that only the societies that can access the correct information in the necessary fields will rapidly rise to the levels of modern states in technology, education and science.

The fact that not every country can reach the global and technical innovations experienced in the field of education at the same level despite contradicting the equal opportunity principle in education and this undermines social justice on a world scale. Furthermore, the capitalist system, which is the crucial basis of globalization, and the states' withdrawal from the market with profit-oriented and competitive neoliberal policies, the exposure of education to privatization practices also hinders the equal opportunity principle and solidify class stratification in the society in many ways. Neoliberal understanding esteems education as "a profitable activity in itself" (Y1ldiz, 2008, p.23). Moreover, the commercialization of education pushes the low-income classes out of education service.

Similarly, as a result of adopting the neoliberal policies fed by globalization in the education system, individualistic, consumption-focused, and hedonist generations of homo economicus trying to maximize their benefits will be raised through educational institutions, and the philosophy of globalization will be transferred from generation to generation. Education, which can be described as "raising the individuals in compliance with the value judgments and ideals of their society" (Özakpınar, 2002, p. 162) transforms into the activity of raising individuals who are rather useful in terms of the economy by internalizing the globalization process.

Education, a non-profit institution serving the public, "has been integrated into the neoliberal economic circulation by being commercialized as a whole with a profit-oriented business approach and harmonized with the functioning of the free market." (Y1ldiz, 2008, p. 19).

\subsection{Globalization and Media}

One of the three most important actors in the age of globalization in the media is Non-Governmental Organizations (NGOs) and international financial institutions (Canbolat, 2002, p. 9). The advanced computer technology and widespread internet use revolutionized communication as substantial developments have been achieved in the production, acquisition, sharing and protection (preservation) of information. Modern technologies have reduced communication costs, increased its speed and enlarged its domain. "The global information society includes the characteristics of information technologies, which are based on the combination of communication and computer technologies" (Geray, 1994, p. 75). It is observed that both media enterprises and content are globalized in the global world order where information and 
information society is emphasized. The media has assumed the role of processing the basic myths of globalization into the subconscious of the resistance communities and facilitating perceptual acceptance in this process. Series, movies, cartoons, competition and program formats etc., prepared in this direction have a high demand in cross-border markets.

The colonial European countries and the USA joining them later on, have organized the communication infrastructure in the colonies to serve their purposes since the 19th century, when communication technologies began to develop. This has not changed even after the colonies became independent (Girgin, 2002a, p. 48).

A one-way information flow process from the developed to underdeveloped states, with the pioneering technical advantages of developed countries and global powers in the media sector, leads to an unbalanced status quo in communication against less developed countries. In this context, it is stated that two-thirds of the daily news circulation directly or indirectly quarters from New York and that more than two-thirds of the journalists working in major agencies are either American or European, which means that the people view the world through their eyes (Girgin, 2002b, p. 180).

Moreover, unconscious media literacy and information pollution, which is prevalent in every platform, have several negative consequences besides the rapid transformations and advances in media and communication.

\subsection{Globalization and Ecology}

The fact that commercial activities all over the world create ethical problems such as injustice and environmental degradation has made consumers more sensitive to ethical issues and increased the role of ethics in consumption decisions. This case, which emerged ethical consumer groups, unearthed the importance of ethical consumption decisions for the consumer and the environment (Shaw \& Newholm, 2002). Ethical consumers should consider the societal cost criteria while comparing the individual benefit level and price elements of each good they purchase.

Globalization created a consumer society as the consumption craze is supported by creating perceptions such as trends and fashion through platforms such as advertisements, publicity, news, videos, series, movies, television programs, competitions etc. in the visual and audio media. Therefore, the increase in needs and demands of the consumption society and the rapid increase in the world population brought along a constantly increasing total demand as the already scarce production factors and raw materials are needed even more.

Some states have started to search for new resources which resulted in developed countries exploiting the Third World states' sovereignty with various 
excuses (bringing democracy and human rights, etc.) to control the wealth of these countries or invest in them. It is observed that this process transformed the target states dependent on the great powers exploiting their local resources through investments, foreign financing and providing funds.

Moreover, intense, unplanned and unnecessary production operated for profit today with scarce resources regardless of the future, causes resource waste, inefficient use and unfair distribution. The competition is increasingly fierce in global markets for global companies that want to satisfy this high profitpromising demand of the consumer society in the postmodern world as the companies that want to maintain in this system are challenged with the obligation to keep their costs at the lowest possible level. Therefore, production centers are shifting to regions where scarce resources are abundant and cheap, and production is conducted at the cost of destroying the ecological systems in those regions.

The devastated forests, contaminated groundwater and seas, toxic accidents are observable side effects of these risks. If radiation, toxic waste, nuclear activities are the invisible side effects (Beck, 1992, p. 55). Since a sustainable development model that protects the ecological system requires additional costs for companies, most of them omit this aspect of the business and continue to apply production models that damage the global ecosystem.

It is observed that multinational companies producing in the less developed countries are not eager to meet the standards to be followed in matters such as working conditions, quality and hygiene in the production process, and disposal of waste generated during production since they can take advantage of the legal and institutional gaps in underdeveloped countries and the lack of social awareness. This process leads to social, ecological etc., negativities besides an unfair competition environment for other companies.

Although human beings differ from other environmental elements with their features such as intelligence and conscience, they are not the ruler but a part of the ecosystem. Thus, being a part and complement of the environment, people have an important role in ensuring the ecological balance. Particularly, the behaviors they display within the scope of ethical consumption are significant for this balance (Karakoç, 2004, p. 64).

\section{CONCLUSION}

Although nationalism, trade wars and trade protectionism rises from time to time by some events in the world, globalization is an unquestionable phenomenon. An even more prevalent and influential globalization process is almost inevitable especially with the communication, transportation, computer and information technologies in today's world. The main puzzle of this study 
concerns how globalization is perceived by individuals, societies and governments.

The economic dimension plays a dominant role in globalization as it is in every process of life. The fact that production factors and investments can move across borders in an easier, faster and cheaper way has become a beacon of hope for countries suffering from savings and investment scarcity in the low production-low income spiral as they race each other to encourage investments. Globalization is considered as a process that can, for the ones who perceive it positively, salvage the underdeveloped countries out of the vicious circle of poverty and facilitate savings and use it for investments. Other countries shall also grow and develop economically through the capital from developed countries and utilize advanced production technologies.

If all impediments to the cross-border movement of production factors, goods and services, capital are removed, societies shall produce most effectively with its homo economicus urges, and the added value of world production will increase collectively. Everything shall settle down in this developing world as there will be positive developments in all countries in law, fair order and distribution, democracy and human rights. Briefly, globalization is the key to world welfare. Furthermore, globalization lays the groundwork for national development with advantages such promoting democratic values, justice, cultural fusion, a more positive perception towards different cultures and societies, the formation of an information society with technological developments, and facilities in access to information.

The application and effects of globalization show that the process has not worked this way. International capital lost its national dependency and has turned to places with economic advantages. Multinational corporations are transforming into transnational corporations with no loyalty to any state. Furthermore, a frequent conflict between the goals and interests of the corporatocracy and the policies of the nation-states hinders nation-states against established and external international economic forces. Localization movements, another factor that damage the nation-states, also stand out as they sharpen the differences and increase social tensions rather than the adaption of sub-identities by the societies. The social rifts and class problems lead to security and terrorism problems.

Globalization is a process in which capitalism is structured supranational as it is a phenomenon that ignores the Third World. The industrialized countries such as the USA, Japan and Western Europe become stronger and further deepens the development gap between countries. The living conditions of the poor in advanced industrialized countries do not improve with globalization. Therefore, the underlying social forces must struggle against the economic forces of 
globalization. Globalization is thus a form of capitalism and leads to the rule of the capitalist class and the exploitation of the poor. Developed countries can play an active and even decisive role in all kinds of decision-making processes in the countries they invest in, as this results in the less developed and developing countries as they become dependent on investments. Furthermore, cheap raw materials, labor and rich natural resources are exploited by developed countries in the invested countries as new imperialism, cultural colonization use globalization as an important effective tool.

Globalization facilitated the global integration process has made countries more dependent on each other, especially economically, and the effects of the crises experienced in a country and the political decisions have increased on a national scale. This made the less developed and developing countries vulnerable and fragile against the decisions and developments in the developed countries.

One of the consequences of globalization is that American culture has become widespread globally as an ideal. This problem, which is also referred to as "Americanization" or "McDonaldization", is rooted in the rapid spread of the American lifestyle and consumption model in the world and its subconscious as the basis of general acceptability or ideal human model.

Moreover, the adverse effects on ecological systems as the companies are forced by the ruthless global competition to destroy nature for the sake of profitable production. Briefly, although globalization is considered as an ideal process by its supporters, it is observed that the imposed ideology tries to make the economic, political, social and cultural sovereignty of developed countries and especially America, free economy, policies and lifestyle of capitalism practical.

\section{CONFLICT OF INTEREST STATEMENT}

There is no conflict of interest between the authors. (Single Author)

\section{AUTHOR CONTRIBUTIONS}

SA: The idea;

SA: Design;

SA: Collection and / or processing of resources;

SA: Empirical Analysis and / or interpretation;

SA: Literature search;

SA: Writer.

7. FUNDING ACKNOWLEDGEMENTS

This research received no specific grant from any funding agency. 


\section{ETHICS COMMITTEE STATEMENT AND INTELLECTUAL PROPERTY COPYRIGHTS} committee.

This is a study that does not require permission from the ethics

\section{REFERENCES}

Aslanoğlu, R. (1998). Kent, kimlik, küreselleşme. Bursa: Asa Yayınevi.

Beck, U. (1992). Risk society: Towards a new modernity. London: Sage Publications.

Bildirici, S. S. (2010). Dünden bugüne küreselleşme yerelleşme ve Türkiye. M. Talas ve

B. Kara (Ed.) Küreselleşme, yeni dünya düzeni ve yerelleşme ilişkisi (pp. 3945). Ankara: Edge Akademi Yay.

Bozkurt, V. (2000). Küreselleşmenin insani yüzü, küreselleşme: Kavram, gelişim ve yaklaşımlar. Ankara: Alfa Yay.

Canbolat, İ. (2002). Küreselleşen dünya ve Türkiye. Bursa: VİPAŞ Yay.

Cox, R. W. (1986). Social forces, states, and world orders: Beyond International Relations Theory içinde. R. O. Keohane (Der.) Neorealism and Its Critics. (204-255). New York: Columbia University Press.

Dikkaya, M., \& Özyakışır, D. (2008). Küreselleşmenin ekonomi-politĭği. Ankara: Gazi Kitabevi.

Dikkaya, M., \& Üzümcü, A. (2017). Uluslararası ticaret ve finans. Ankara: Savaş Yayınevi.

Geray, H. (1994), Yeni iletişim teknolojileri. Ankara: Kılıçaslan Matbaacılık.

Giddens, A. (1990). The consequence of modernity. Cambridge, MA: Stanford University Press.

Girgin, A. (2002a). Uluslararası iletişim haber ajansları ve A.A. İstanbul: Der Yayınları.

Girgin, A. (2002b). Uluslararası haber ajansları. İstanbul Üniversitesi İletişim Fakültesi Dergisi, 12 (1). 169-185.

Gray, J. (2006). Küresel yanılgılar. (çev. Zerrin Koltukçuoğlu), İstanbul: Etkileşim Yay.

Hirst, P., \& Thompson, G. (1998). Küreselleşme sorgulanıyor. (çev. Çağla Erdem, Elif Yücel). Ankara: İmge Yay.

Hobbs, S. (2005). The Titanic headline. 3 Mart 2021 tarihinde http://www.folklore.ee/FOAFtale/ftn61.htm adresinden erişildi.

İlhan, A. (2019). Hangi küreselleşme. İstanbul: Türkiye İş Bankası Kültür Yayınları.

Karabıçak, M. (2002). Küreselleşme sürecinde gelişmekte olan ülke ekonomilerinde ortaya çıkan yönelim ve tepkiler. Süleyman Demirel Üniversitesi İktisadi ve İdari Bilimler Fakültesi Dergisi, 7 (1), 115-131.

Karakoç, A. G. (2004). Çevre sorunlarına etik yaklaşım. M. C. Marın ve U. Yıldııım (Ed.) Çevre Sorunlarına Çağdaş Yaklaşımlar (pp. 31-57). İstanbul: Beta Yayınları.

Kazgan, G. (2000). Küreselleşme ve ulus devlet. İstanbul: İstanbul Bilgi Üniversitesi Yay.

Keyman, E. F. (2000). Küreselleşme, devlet, kimlik/farklılık: Uluslararası ilişkiler kuramını yeniden düşünmek. İstanbul: Alfa Basım Yayım Dağıtım.

Kızılçelik, S. (2012). Küreselleşme ve sosyal bilimler. Ankara: Anı Yayıncılık. 
Koray, M. (2005). Reel küreselleşme veya küreselleşmenin realitesi. Çalışma ve Toplum Dergisi, 2005/4 (7), 11-45.

Köse, A. H. \& Öncü, A. (2003). İktisadın piyasası, kapitalizmin ekonomisi. İktisat Üzerine Yazılar 1-Küresel Düzen: Birikim, Devlet ve Sınıflar, (Derleyenler: Ahmet Haşim Köse, Fikret Şenses, Erinç Yeldan), İstanbul: İletişim Yay.

Kutlu, E. (1998). Dünya ekonomisi. Eskişehir: Anadolu Üniversitesi Basımevi.

Mackay, H. (2004). Press \& Journal sinks the Titanic newspaper myth. 2 Mart 2021 tarihinde https://www.pressgazette.co.uk/press-journal-sinks-the-titanicnewspaper-myth/ adresinden erişildi.

Manfred, B. S. (2003). Küreselleşme. (çev. Abdullah Ersoy), Ankara: Dost Kitabevi Yay.

Mcluhan, M. (2014). Gutenberg galaksisi. (çev. Gül Çağalı Gülen), İstanbul: Yapı Kredi Yayınlar1.

Nye, Jr. J. S. \& Welch, D. A. (2010). Küresel çatışmayı ve işbirliğini anlamak. (çev. Renan Akman), İstanbul: Türkiye İş Bankası Kültür Yayınları.

Özakpınar, Y. (2002). İnsan düşüncesinin boyutları. İstanbul: Ötüken Neşriyat.

Przeworski, A. (1994). Neoliberal yanılg1" [Kapitalizm, sosyalizm ve demokrasi: Yeni değerlendirmeler], (Derleyenler: Larry Diamond ve Marc F.Plattner), (çev. Ergun Özbudun ve Levent Köker), Ankara: Türk Demokrasi Vakfı Yayınları.

Robertson, R. (1998). Globalization: Social theory and global culture. London, Thousand Oaks, New Delhi: Sage Publications.

Rodrik, D. (2011). Akıllı küreselleşme. (çev. Burcu Aksu), Ankara: Efil Yayınevi.

Shaw, D. \& Newholm, T. (2002). Voluntary simplicity and the ethics of consumption. Psychology \& Marketing, 19(2), 167-185.

Stiglitz, J. E. (2018). Küreselleşme büyük hayal kırıklığı. (çev. Arzu Taşçıŏlu ve Deniz Vural), İstanbul: Alfa Basım Yayım Dağıtım.

Tatlıdil, E. \& Esgin Günder, E. (2013). Küreselleşen değerlerin eğitim kurumları üzerine etkisi, Değerler Eğitimi Dergisi, 11 (26), 259-277.

Tomlinson, J. (2017). Küreselleşme ve kültür. (çev. Arzu Eker), İstanbul: Ayrıntı Yayınlar1.

Tutal, N. (2006). Küreselleşme iletişim kültürlerarasılık. İstanbul: Kırmızı Yayınları.

Weber, M. (1985). Protestan ahlakı ve kapitalizmin ruhu. (çev. Z. Aruoba), İstanbul: Hil Yayınevi.

Yeldan, E. (2002). Neo liberal küreselleşme ideolojisinin kalkınma söylemi üzerine değerlendirmeler, Praksis, 7, 19-34.

Yeldan, E. (2003). Neoliberalizmin ideolojik bir söylemi olarak küreselleșme. İktisat Üzerine Yazılar 1-Küresel Düzen: Birikim, Devlet ve Sınıflar, (Derleyenler: A.H.Köse, F. Şenses, E. Yeldan), İstanbul: İletişim Yay.

Yeldan, E. (2016). Küreselleşme sürecinde Türkiye ekonomisi bölüşüm, birikim ve büyüme, İstanbul: İletişim Yayınları.

Yıldız, N. (2008). Neoliberal küreselleşme ve eğitim. D.Ü. Ziya Gökalp Eğitim Fakültesi Dergisi, 11, 13-32. 
Yıldız, S. (2010). İşletme performansının ölçümü üzerine bankacılık sektöründe bir araştırma. Erciyes Üniversitesi İktisadi ve İdari Bilimler Fakültesi Dergisi, 36, 179-193.

Yıldız, S. (2011). Entelektüel sermaye. İstanbul: Türkmen Kitabevi. 